\title{
ARHITECTURA VERNACULARĂ A ȘVABILOR SĂTMĂRENI ${ }^{1}$ / VERNACULAR ARCHITECTURE OF SATHMAR SWABIANS
}

Maria BOSTENARU DAN, dr. arh. cercetător/ dr. Dipl.-Ing. researcher

Maria.Bostenaru-Dan@alumni.uni-karlsruhe.de

Universitatea de Arhitectură şi Urbanism „Ion Mincu”, Bucureşti, RO/

„Ion Mincu” University of Architecture and Urbanism, Bucharest, RO

\begin{abstract}
Rezumat
Aceasta este o tipologie de arhitectură vernaculară cu privire la care au existat diferite teze dacă acestea derivă din locurile de origine de imigrare sau au fost însușite în interacțiune cu locurile în care s-au așezat coloniștii. Ne-am axat pe locuințele vernaculare ale șvabilor sătmăreni. Spre deosebire de șvabii bănățeni, acești coloniști au fost aduși de contele de Károlyi, conte maghiar, și nu central de la Viena de Maria Tereza. Mai mult, este vorba de un grup etnic unitar, toți originari din Suabia Superioară din regiunile Biberach și Ravensburg. În această cercetare am vizitat muzeul Suabiei Superioare din Kürnbach, care cuprinde case din ultimii 500 de ani, deci și dinainte de emigrare, și muzee ale satului din
\end{abstract}

\begin{abstract}
This is a typology of vernacular architecture regarding which there have been different hypotheses if it is derived from the origin places of the immigrants or was a result of the interaction with the places where the colonists settled. I focused on the vernacular housing of Sathmar Swabians. Different from the Banat Swabians, these colonists were brought by the Károlyi count, a Hungarian count, and not centrally from Vienna by Maria Theresia. More even, it is about a unitary ethnical group, all from Upper Suabia, namely the regions Biberach and Ravensburg. Within this research I visited the Upper Suabia village museum in Kürnbach, which contains houses from the last 500
\end{abstract}

\footnotetext{
${ }^{1}$ Cercetarea a fost finanțată de o bursă DOMUS în patrie a Academiei Maghiare./ Research was funded by a DOMUS scholarship in the home country of the Hungarian Academy of Sciences.
} 
România (Astra și București), unde însă am găsit case bănățene. Am vizitat muzeul șvabilor din Petrești, județul Satu-Mare, o casă conservată in situ, construită la 1871. Și de asemenea o casă a strămoșilor proprii, pe care Forumul Democrat al Germanilor din România o renovează ca spațiu de expoziție. Această casă datează dinainte de 1850. Din cercetarea bibliografică reiese că și șvabii din Ungaria (muzeul din Szentendre) au aceeași tipologie de casă. Amenajarea de interior a locuinței svabilor sătmăreni poate fi studiată în afară de localitatea Petrești şi la muzeul central al șvabilor din UIm. Locuințele șvabilor sătmăreni au fost relevante și pentru cercetarea privind cutremurul din Érmellék din 1834 în care intensitatea seismică a fost măsurată pe baza avariilor la acest tip de case vernaculare. Din acest motiv am modelat casa tipică în 3D și am colectat datele de vulnerabilitate seismică. Este posibil ca tipologia moștenită din Suabia Superioară să fi dispărut ca urmare a cutremurului având în vedere că avem păstrate case care au această vârstă.

\section{Cuvinte cheie/ Keywords}

muzeul satului, migrație, seism/ village museum, migration, earthquake years and thus also from before immigration, as well as village museums in Romania (Astra and Bucharest), where however Banat houses were found. I visited the Swabian Museum in Petrifeld, Sathmar county, a house conserved in situ, built 1871. And a house of the own ancestors, in course of renovation by the Democratic Forum of Germans in Romania as exhibition space. This house dates from before 1850. From literature review it results that also the Danube Swabians in Hungary (village museum in Szententre) have the same house typology. The interior design of the housing of Sathmar Swabians can be investigated apart of Petrifeld also in the central museum of Swabians in Ulm. Sathmar Swabian vernacular housing has been relevant also for research regarding the 1834 Érmellék earthquake in which seismic intensity was measured on the bases of the damages caused to them. It is possible that the typology inherited from Upper Suabia disappeared after the earthquake, taking into account the age of the houses remaining today.

\section{Imigrarea șvabilor}

Șvabii sătmăreni sunt primii coloniști șvabi din perioada contrareformei. La începutul secolului al XVIII-lea, zona din estul Câmpiei Panonice (acum Câmpia de Vest din România) fusese lăsată pustie de năvălirile turcilor și lipsea forța de muncă pentru pământ, un pământ roditor până astăzi, de altfel. În această zonă, zona Satu-Mare, erau moșiile unei străvechi familii de conți maghiari, conții Károlyi.

\section{Swabian immigration}

Sathmar Swabians are the first Swabian colonists from the Counter-Reformation time. At the begin of the 18th century, the region in the East of the Pannonian field (now West Field in Romania) has been left empty by Turkish battles and work force for land was missing, a land which is fruitful even today. In this zone, the Sathmar zone, were the lands of an ancient family of Hungarian counts, the Károlyi 
După ce s-a încheiat pacea de la Satu-Mare în 1711, a urmat o perioadă liniștită în care contele a adus vreme de 100 de ani coloniști germani din Suabia superioară. Exemplul contelui a fost urmat de împărăteasa Maria Tereza care a adus coloniști germani catolici în cadrul Contra-Reformei în perioada imediat următoare în Banat și Ungaria. Spre deosebire de aceștia, șvabii sătmăreni proveneau dintr-un grup etnic omogen, toți din Suabia Superioară, cu precădere din zona Biberach și Ravensburg. Motivele venirii lor nu sunt clare, pentru că în această perioadă în zona de origine a început o amplă activitate de constructie pentru ridicarea de biserici baroc pentru mănăstirile ale căror pământuri le lucrau tăranii șvabi, stilul baroc făcându-și apariția în întreaga Europă tot în cadrul Contrareformei Bisericii. Astăzi zona este cunoscută pentru cea mai veche rută culturală din Germania, de mai mult de 50 de ani, și anume Strada Baroc a Suabiei Superioare. Unele din aceste biserici sunt importante pentru istoria arhitecturii, cum ar fi cele din Sankt Gallen (UNESCO) sau Ottobeuren, ambele fiind parte a unor mănăstiri unde s-au construit și frumoase biblioteci în același stil, fapt întâlnit și la Bad Schussenried și Wiblingen. Importante sunt și bisericile din Zwiefalten, Einsiedeln, Rott-am-Inn, și Steinhausen. Mulți dintre coloniști au venit din astfel de localități, zona fiind bogată în mănăstiri. Și în Suabia Superioară avântul constructiv a început la încheierea unui război, războiul de 30 de ani. Autoarea consideră că poate valul de emigrare a fost cauzat și de această frenezie a construcției, care lua bărbații de la munca câmpului, precum în romanul lui Jose Saramago (1982), "Memorial do convento" în original, despre construcția mănăstirii din Mafra, proiectată de un arhitect șvab, dar din nord. counts. After the Sathmar peace from 1711 a silent period followed in which the count brought 100 years long German colonists from Upper Suabia. The example of the count was followed by Maria Theresia who brought catholic German colonists in frame of the Counter Reformation in the immediate following period in Banat and Hungary. Different from these, the Sathmar Swabians were originar from a homogenous ethnical group, all from Upper Suabia, mainly the zones around Biberach and Ravensburg. The reasons why they came are not clear, given the fact that in this period in the origin one a tremendous construction activity started to raise Baroque churches for the monasteries the land of which was worked by Swabian peasants, since the Baroque style spread over Europe also in frame of the Church counterreformation. Today the one is known for the oldest cultural route in Germany, older than 50 years, namely the Upper Swabian Baroque Street. Some of these churches are important for the history of Architecture, like those in Sankt Gallen (UNESCO) or Ottobeuren, both part of monasteries in which there are also beautiful libraries in the same style, fact occuring also in Bad Schussenried and Wiblingen. Important are also the churches in Zwiefalten, Einsiedeln, Rott-am-Inn, and Steinhausen. Numerous colonists came from such localities, the zone being rich in monasteries. Also in Upper Suabia the constructive activity started at the closure of a war, the 30 years war. The author considers that maybe the emmigration wave was caused by this tremendous construction activity, which took men from land work, like in the novel of Jose Saramago (1982), "Memorial do convento" in original, on the construction of the Mafra monastery, designed also by a Swabian architect, but from the North. 

malul șvabilor dunăreni de la UIm, în apropierea Muzeului Șvabilor Dunăreni. Acest muzeu găzduiește acum camera tipic sătmăreană, care înainte se afla la muzeul satului Suabiei Superioare din Kürnbach.

\section{Arhitectura șvabilor}

În cadrul cercetării am investigat clădirile ecleziastice și arhitectura vernaculară. În cazul clădirilor ecleziastice, cele din Satu-Mare se deosebesc de cele din Suabia Superioară în stil, acestea din urmă fiind pictate mult mai bogat. De asemenea, spre deosebire de Banat, pentru zona contelui Károlyi au fost aduși arhitecți din străinătate (din Viena și Würzburg) dar aceștia nu au fost la fel de renumiți ca cei care au proiectat catedralele din Timișoara și Oradea. Există puțină bibliografie despre arhitectura din această zonă, și până în prezent nici o monografie cuprinzătoare, studiile fiind mai mult antropologice. Există o dispută privind originea austriacă versus originea germană a arhitecturii de aici. Și în zona Suabiei Superioare de unde au venit coloniștii au activat arhitecți austrieci, și anume Școala din Voralberg, familiile de arhitecți Thumb și Beer, dar mai ales Dominikus Zimmermann, arhitectul de la Steinhausen, cea mai frumoasă biserică rurală din lume.

La cramele Recaș din județul Timiș e produs și vinul „Schwaben Wein" (vin șvăbesc) pe a cărui etichetă figurează o așa-numită Schwaben Haus (casă șvăbească). Acesta este un tip de arhitectură vernaculară cu privire la care există diferite teze. Panasiu (2007) susține ipoteza însușirii de către coloniști a arhitecturii locale, în vreme ce Pavlovici the colonists. In 2018, on the 8th of September, also the plate of Swabians was inaugurated on the shore of Danube Swabians in UIm, close to the Museum of Danube Swabians. This museum houses now the typical Sathmar Swabian house, which had been before at the museum of Upper Swabia in Kürnbach (Bad Schussenried).

\section{The architecture of the Swabians}

In frame of the research I investigated church buildings and vernacular architecture. In case of church buildings, those in Sathmar are different of those in Upper Suabia in style, the latter being more richly painted. Also, different from Banat, for the zone of the Károlyi count foreign architects were brought (from Vienna and Würzburg) but these were not so renowned as those who designed the cathedrals in Temeschwar and Oradea (Großwardein). There are few litterature references for this zone, and up to the present no complete monography, the studies being more in the anthropologic zone. There is a discussion regarding the Austrian origin versus the german origin of the architecture here. Also in the zone of Upper Suabia there are Austrian architects, namely the school in Voralberg, the architect families Thumb and Beer, but mainly Dominikus Zimmermann, the architect in Steinhausen, the most beautiful village church of the world.

At the Recaș wineries in Timiș county the "Schwaben Wein" (Swabian vine) is produced, featuring the socalled Schwaben Haus (Swabian house). This is a typology of vernacular architecture regarding which there are different hypotheses. Panasiu (2007) sets forth the hypothesis according to which the housing typology in the settlement places whas taken over 
(Săbăilă) (2013) susține ipoteza aducerii unei tipologii din locurile de origine. Ambele teze menționate privind interacțiunea cu locurile unde sau așezat coloniștii se referă la șvabii bănățeni, o casă tipică a acestora fiind reprezentată pe sticlă. Dar aceste case au fost în mare parte case tip, proiectate în Austria (conform Bara, 2015 și Volkmann, 2001), ultima referință prezentând modele din expoziția de la Muzeul Central al Șvabilor Dunăreni din UIm.

Diferit de șvabii bănățeni, coloniștii din Satu-Mare au fost aduși de contele maghiar Károlyi, și de conducerea centrală imperială. Este un grup etnic unitar, toţi originari din Suabia superioară (Vonház, 1931), din regiunile Biberach și Ravensburg. Am vizitat muzeul din Suabia Superioară din Kürnbach (Kniep, 2014), care conține case din ultimii 500 de ani (Schmid, 1976) (Fig. 2), deci din perioada dinaintea emigrării. Alte muzee ale satului pentru arhitectura șvăbească din Germania sunt cele din Wolfegg în Baden-Württemberg (BauernhausMuseum Allgäu-Oberschwaben Wolfegg www.bauernhausmuseum-wolfegg.de) și Illerbeuren în Bavaria (Schwäbisches Bauernhofmuseum Illerbeuren www.bauernhofmuseum.de). Spre deosebire de cel din Kürnbach acestea sunt bine documentate online și nu au fost vizitate.

Au fost vizitate și muzee ale satului din România (ASTRA în Sibiu și cel din București), în ultimul fiind case din Banat. Acestea sunt casa din Borlova, județul Caraş-Severin, 1897 (muzeulsatului.ro/planifica-vizita/ce-pot-vedea/expozitiapermanenta-arhitectura- by the colonists while Pavlovici (Săbăilă) (2013) sets forth the hypothesis according to which the colonists brought with them architecture from the origin places. Both mentioned hypotheses regarding the interaction with the places where the colonists settled regard Banat Swabians, a typical house of these being represented on glas. But these were houses to great part designed as typical houses in Austria (Bara, 2015, Volkmann, 2001) the last reference representing models from the exhibition of the Central Museum of the Danube Swabians in UIm.

Different from the Banat Swabians, the colonists in Sathmar were brought by the Hungarian county Károlyi and not by the central imperial leadership. It is a unitary ethnical group, all originar from Upper Suabia (Vonház, 1931), from the regions Biberach and Ravensburg. I visited the Museum of Upper Suabia in Kürnbach (Kniep, 2014) which contains house from the last 500 years (Schmid, 1976) (Fig. 2 ), so also from the time before immigration. Other village museums for Swabian architecture in Germany are those in Wolfegg in BadenWürttemberg (Bauernhaus-Museum AllgäuOberschwaben Wolfegg www.bauernhausmuseumwolfegg.de) and Illerbeuren in Bavaria (Schwäbisches Bauernhofmuseum Illerbeuren www.bauernhofmuseum.de). Different from the one in Kürnbach these are well documented online and were not visited.

Also village museums in Romania (ASTRA in Sibiu/Hermannstadt and the one in Bucharest) were visited, along with the Banat houses in the latter. These are the house in Borlova, Caraş-Severin county, 1897 (muzeul-satului.ro/planifica-vizita/cepot-vedea/expozitia-permanenta-arhitectura- 
vernaculara/gospodarii/borlova-judetul-carasseverin-1897/) și cea din Sârbova, județul Timiș, 1821 (muzeul-satului.ro/planifica-vizita/ce-potvedea/expozitia-permanenta-arhitecturavernaculara/gospodarii/sarbova-judetul-timis1821/). Am vizitat Muzeul Svabilor din Petrești, județul Satu-Mare, o casă conservată in situ, construită în 1881 (Fig. 3) și casa strămoșilor (Fig. 4), în curs de restaurare pentru a deveni un spațiu expozițional al Forumului Democrat al Germanilor din România. Interiorul casei svabilor sătmăreni poate fi studiat în afară de Petrești la muzeul central din UIm, de asemenea vizitat.

Din consultarea bibliografiei putem spune că și șvabii din Ungaria (Muzeul satului din Szentendre) au aceeași tipologie de casă. În Ungaria am văzut case similare in situ în zona Pécs. Arhitectul Imre Makovecz (Bostenaru, 2011) a proiectat la reconstrucția după catastrofa chimică de la Ajka la Kolontár și Devecser case urmărind tipologia șvăbească a coloniștilor respectivi (Fig. 6). Și la Visegrád proiectase în stil Fachwerk similar casei din Kürnbach din Fig. 2 o sală de sport, aceasta fiind tot o zonă a coloniștilor șvabi.

În cadrul cercetării am participat la un workshop al lui Karsten Michael Drohsel la festivalul de film Urban Eye, unde a fost proiectat un joc de societate. Subiectul acestui joc era migrația a ceva material, legat de case, inițial a unei bucăți de tencuială dintrun cartier în altul, pe urmă a ceva neprecizat în mod similar indicării unei călătorii pe social media. Acest joc se poate adapta la preluarea unor elemente din arhitectura germană în cea a coloniștilor germani, ipoteza de cercetare din această contribuție. vernaculara/gospodarii/borlova-judetul-carasseverin-1897/) and the one in Sârbova, Timiș county, 1821 (muzeul-satului.ro/planifica-vizita/ce-potvedea/expozitia-permanenta-arhitecturavernaculara/gospodarii/sarbova-judetul-timis1821/). I visited the Swabian Museum in Petrifeld, Sathmar county, a house conserved in situ, constructed 1881 (Fig. 3) and also the house of the ancestors (Fig. 4), in course of being restored to became exhibition space of the Democratic Forum of Germans in Romania. The Interior of the Sathmar Swabian houses can be seen apart of Petrifeld in the Central Museum in Ulm, also visited.

From the study of literature we can say that also the Swabians in Hungary (village museum in Szentendre) have the same house typology. In Hungary I saw similar houses in situ in the Pécs zone. The architect Imre Makovecz (Bostenaru, 2011) designed the reconstruction after the chemical catastrophe in Ajka for Kolontár and Devecser employing houses which follow the Swabian typology of the respective colonists (Fig. 6). Also in Visegrád he had designed a sports hall in a similar Fachwerk style as the house in Kürnbach in Fig. 2, since this is also a zone of Swabian colonists.

In frame of the research I participated at a workshop of Karsten Michael Drohsel at the Urban Eye film festival, where a board game was designed. The subject of this game was the migration to something material, connected to houses, initially a plaster piece from a neighbourood to another, then of something not defined in a similar way during a journey on social media. This game can be adapted to taking over elements from German architecture in that of German colonists, the research hypothesis in this contribution. 
În afară de ruta culturală a bisericilor baroc, în Suabia superioară este și o rută culturală a morilor, care a împlinit în 201810 ani. Și această arhitectură vernaculară este diferită în zona de origine, unde morile sunt din zidărie, de cea populară din țara noastră, din lemn.

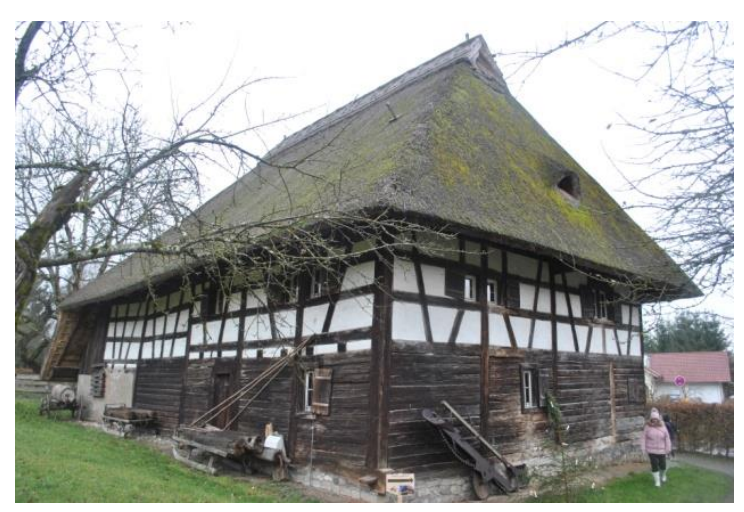

Apart of the cultural route of Baroque churches, in Upper Suabia there is also a cultural route of mills, which was 10 years old in 2018. Also this architecture is different at the colonists from the origin places, where the mills are out of masonry and those in our country of timber.

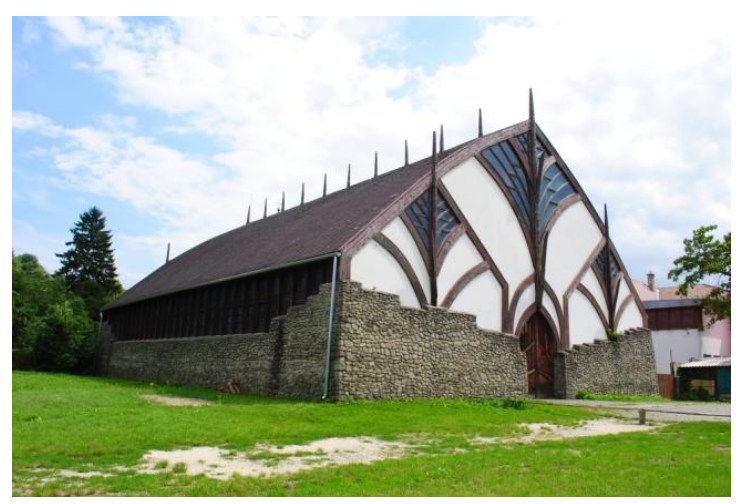

Fig. 2: Casă tipică din Muzeul Satului din Kürnbach (stânga) sală de sport a lui Imre Makovecz la Vișegrad, 1985 în același stil (dreapta)./

Typical house in the Village Museum in (left) and sports hall of Imre Makovecz in Vișegrad, 1985 in similar style (right). Foto: M. Bostenaru.
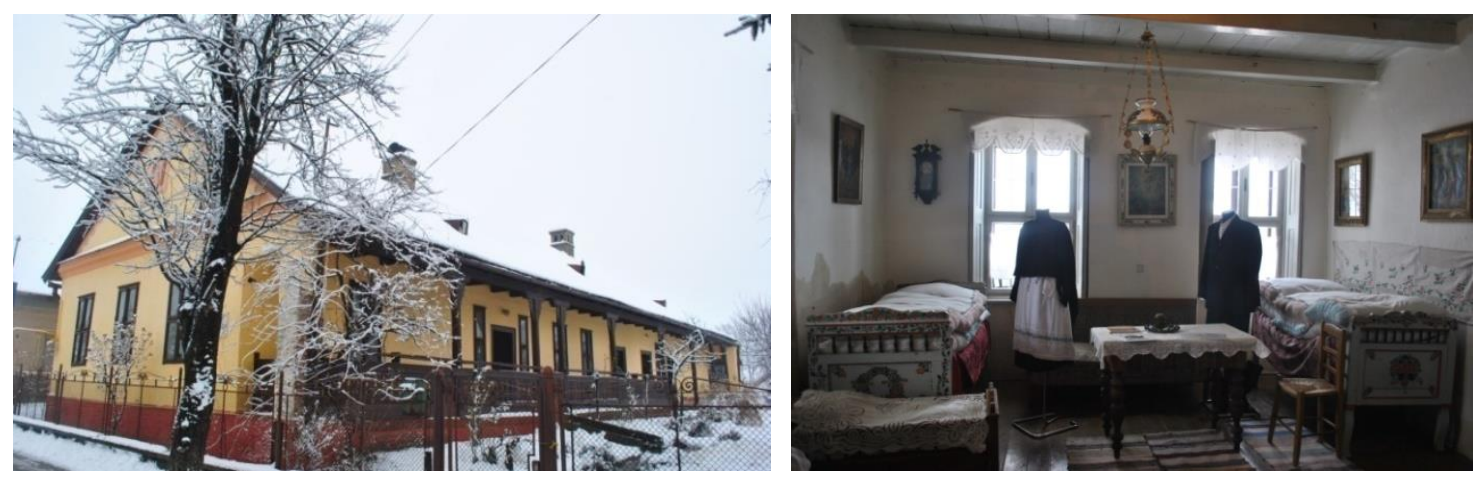

Fig. 3: Muzeul șvabilor din Petrești./ Swabian museum in Petrifeld. Foto: M. Bostenaru. 

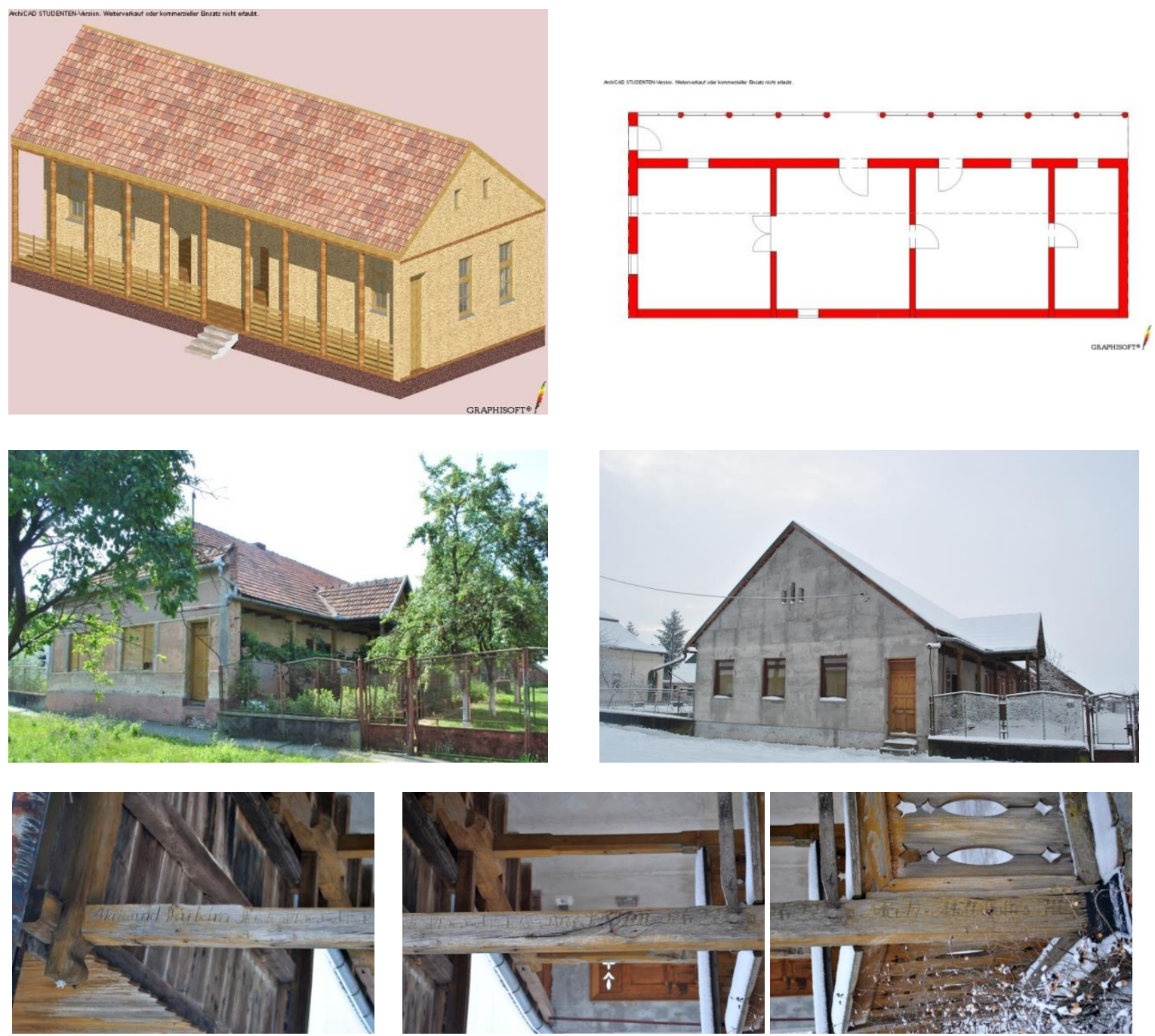

Fig. 4: Casa strămoșilor din Foieni (vezi arborele genealogic din Fig. 5): model 3D (Bostenaru, 2010), casa înainte (2014) și în timpul (2019) restaurării și grinda meșter./

The ancestors house in Fienen (see the family tree in Fig. 5): 3D model (Bostenaru, 2010), the house before (2014) and during (2019) restoration and the master beam. Foto: M. Bostenaru. 


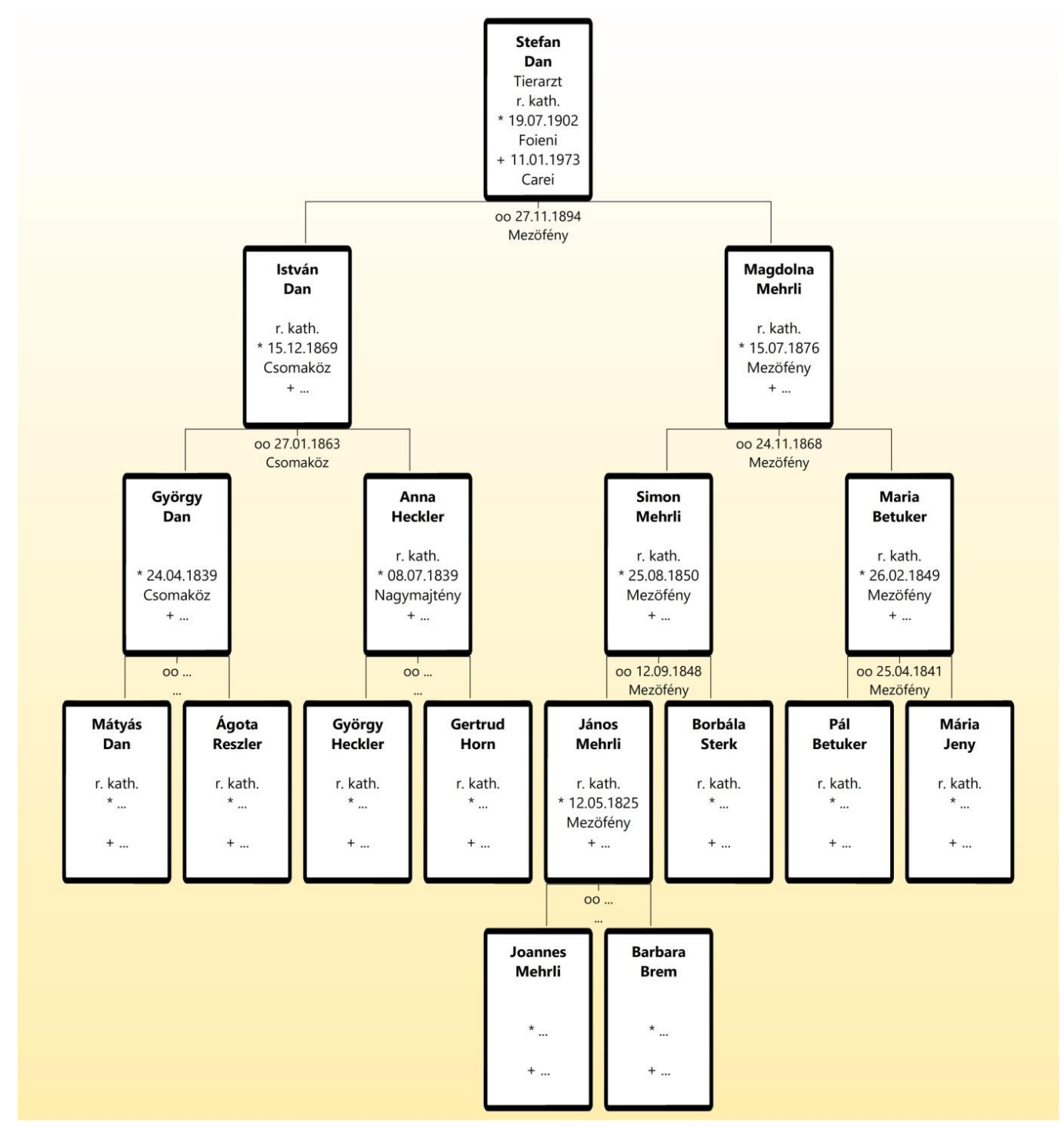

Fig. 5: Arborele genealogic al unei familii șvăbești din Foieni, cei care au construit casa (János Merli și Barbara Sterk)./ Family tree of a Swabian family in Fienen, those who built the house(János Merli and Barbara Sterk). 

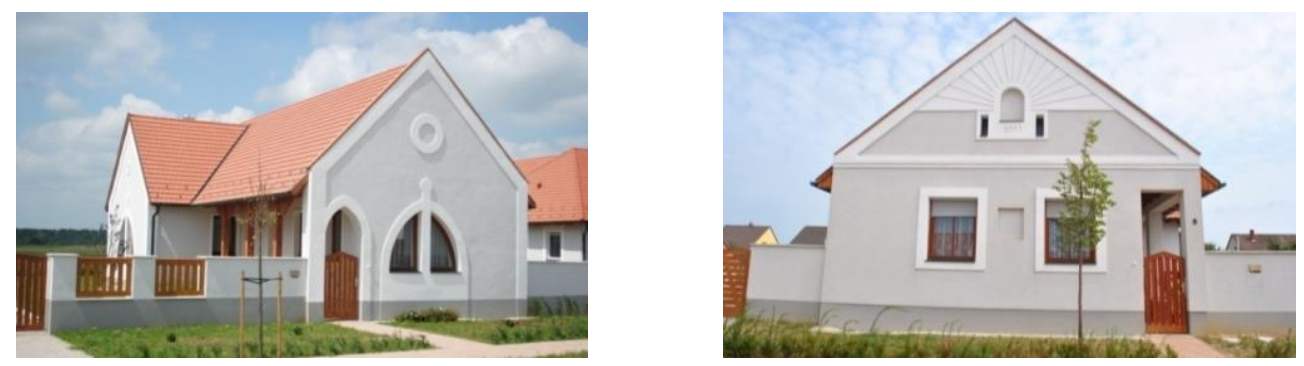

Fig. 6: Reconstrucția Kolontár după catastrofa chimică de la Ajka, Imre Makovecz, 2011.

O reconstrucție similară a fost la Devecser, ambele zone locuite de șvabi./

Reconstruction in Kolontár after the chemical catastrophe at Ajka, Imre Makovecz, 2011.

A similar reconstruction was in Devecser, both zones inhabited by Swabians. Foto: M. Bostenaru.

\section{Efectele cutremurului din Érmellék 1834}

Casele șvabilor sătmăreni sunt relevante și pentru cercetarea lui Zsíros (1983) privind cutremurul din Érmellék din 1834 în care intensitatea seismică a fost măsurată utilizând avariile suferite de aceste locuințe vernaculare. Din acest motiv casa a fost modelată în 3D și au fost colectate date privind vulnerabilitatea seismică (Bostenaru, 2010) (Fig. 7). Este posibil ca tipologia moștenită din Suabia superioară să fi dispărut dat fiind că au această vârstă și casele, datare posibilă și folosind arborele genealogic din Fig. 5 printre altele.

În urma colonizării șvabilor sătmăreni, harnici lucrători ai ogorului, contele Károlyi și-a extins averea și puterea în tot regatul Ungariei de atunci. Familia a construit numeroase castele până în zona Slovaciei, inclusiv la Budapesta. Arhitectul multora dintre aceste castele, construite în secolul al XIXlea, a fost Miklos Ybl, cel mai important arhitect al Ungariei din toate timpurile. Miklos Ybl a devenit arhitectul familiei Károlyi după ce atunci când era tânăr, a fost chemat pentru reconstrucția zonei

\section{Efects of the 1834 Érmellék earthquake}

The houses of Sathmar Swabians were relevant also for the research of Zsíros (1983) regarding the 1834 Érmellék earthquake, for which seismic intensity was measured on the basis of the damages on these vernacular housing units. For this reason I modelled in $3 \mathrm{D}$ and collected data regarding seismic vulnerability (Bostenaru, 2010) (Fig. 7). It is possible that also the typology inherited from Upper Suabia disappeared given the age of the buildings from after the earthquake, age which could be set using the family tree in Fig. 5 among others.

Following the arrival of the colonists, hard working people of land, the Károlyi count extended his wealth and power in the whole Hungarian kingdom of that time. The family built numerous castles up to the zone of Slovakia, including in Budapest. The architect of many of these castles, built during the 19th century, was Miklos Ybl, the most important architect of Hungary of all times. Miklos Ybl became the architect of the Károlyi family after, when he was young, he was called for the reconstruction of the 
Carei în urma cutremurului din 1834 din Érmellék. O realizare de seamă a acestuia a fost biserica și cripta familiei Károlyi de la Căpleni.
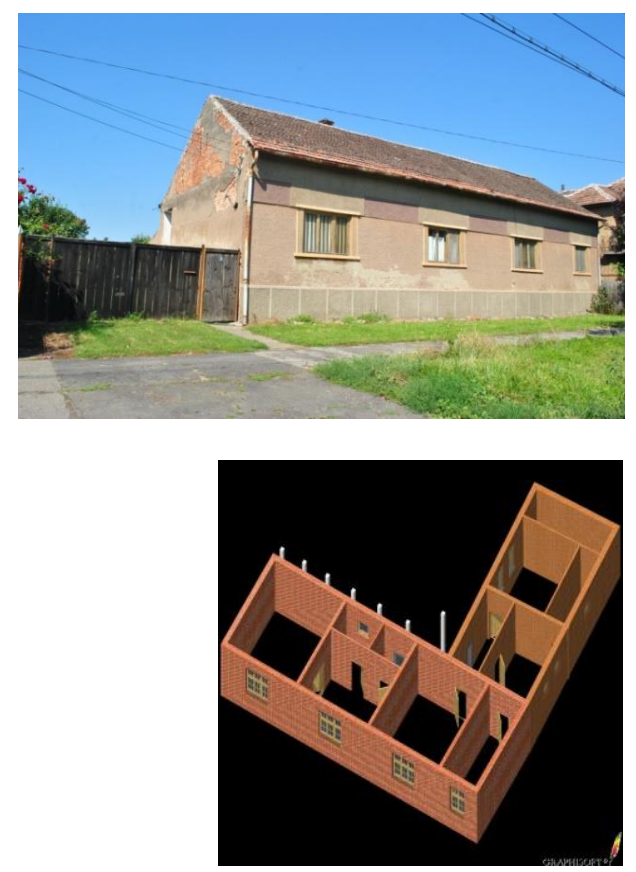

Carei (Großkarol) zone after the 1834 Érmellék earthquake. A notable building of him was the church and the cripta of the Károlyi family in Căpleni (Kaplau).
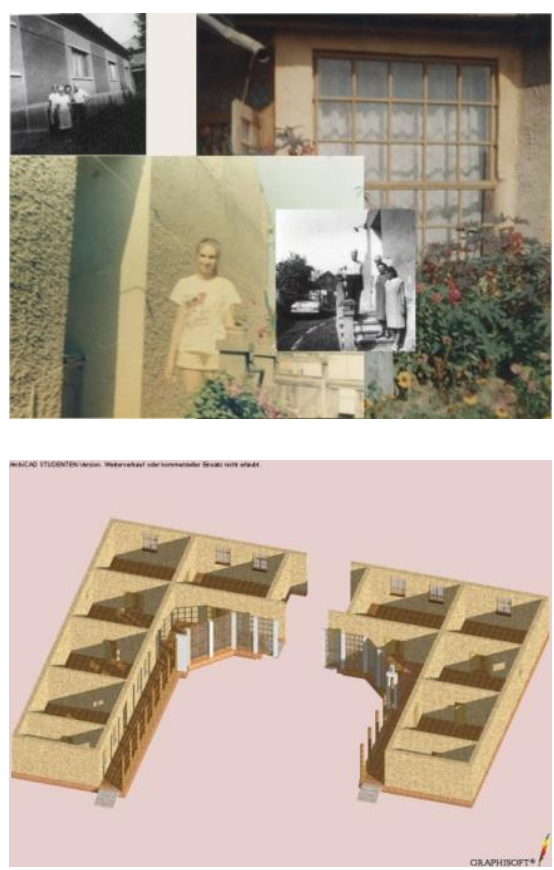

Fig. 7: Varianta de casă șvăbească din Carei: fotografii din curte și de la stradă, model 3D (jos, stânga) precum și o casă șvăbească ideală pe baza unui plan de "Querhaus" (casă transversală). Casa funcționa ca grădiniță la începutul secolului.

După casa șvăbească tradițională ca "Langhaus" (casă longitudinală) (Fig. 4) (Haslmayr és Corbea-Hoisie, 2013) și

"Halbquerhaus" (casa semitransversală) a fost dezvoltată și "Querhaus" pentru populația bogată. Casa din strada Petőfi Sándor nr. 63 e o "Querhaus", forma de L s-a dezvoltat prin extensii. Desene Bostenaru (2010). Foto: din arhiva familiei./

Variation of the Swabian house in Carei: photographs from the courtyard and from the street, 3D model (bottom, left) as well as an ideal Swabian house on the basis of a "Querhaus" plan (transversal house). The house was initially a Kindergarten at the begin of the century. After the traditional Swabian house as "Langhaus" (longitudinal house) (Fig. 4) (Haslmayr és Corbea-Hoisie, 2013) and "Halbquerhaus" (semitransversal house) also the "Querhaus" was developed for the richer population. The house in Petőfi Sándor street nr. 63 is a "Querhaus", the L shape developped through extensions. Drawings Bostenaru (2010). Photo: family archive. 


\section{Perspective de viitor}

În contextul migrației minorității germane înapoi în Germania în secolul al XX-lea până astăzi, este o ipoteză de cercetare ce se întâmplă cu patrimoniul construit moștenit din România, chiar dacă nu este la fel de cunoscut precum cel al sașilor transilvăneni, cum a fost influențat de migrație în urmă cu 300 de ani și cum este influențat de migrația opusă astăzi.

Pe parcursul timpului, șvabii sătmăreni au pierdut uzul limbii germane în cadrul unui proces puternic de maghiarizare. Străbunicii subsemnatei în jur de 1900 vorbeau șvăbește, dar copiii acestora, dintre care bunicul a studiat la Budapesta, nu îi mai înțelegeau. Acesta nu e un caz singular și este momentan studiat de cercetători (Roșu, 2015). În același timp, puținii care vorbesc șvăbește, colectează folclorul zonei în volume recent publicate (Wohnhas, 2005). Până astăzi unii din cei bătrâni vorbesc ungurește și nu românește. După 1989 au fost reînființate școlile germane și tinerii vorbesc deja germana literară. Amestecul maghiaro-german conduce la asocieri stranii în numele locuitorilor, cu prenume maghiare și nume de familie germane, ultimele nefiind însă nici traduse, nici scrise cu ortografie maghiară, în cele mai multe din cazuri. În vorbirea în limba maghiară sunt expresii germane însușite, pe care ungurii din Ungaria nu le înțeleg, cum ar fi Kirbáj (o nouă ortografie pentru Kirchweih) pentru hramul bisericii în loc de búcsú - uzual în Ungaria, sau speiz de la Speisekammer pentru cămară, sau vájbusli pentru Weihbusch, obicei pentru coronița de 15 august (Muzeul Județean Satu-Mare, 2009). De asemenea, s-a păstrat o combinație interesantă a bucătăriei svăbești, cu anumite influențe austriece. Unele bucate sunt însă

\section{Outlook}

In the context of the migration of the German minority back to Germany from the 20th century till today, there is a research hypothesis what happens to the built heritage in Romania, even if it is not so known as that of the Transsylvanian Saxons, how it was influenced by migration 300 years ago and how it is influenced by opposed migration today.

Over time, Sathmar Swabians lost the use of German language during a strong magyarisation process. The great-grandparents of the author around 1900 spoke Swabian, but their children, also the grandfather who studied in Budapest, did not understand the language anymore. This is not a singular case and it is researched today (Roșu, 2015). Simultaneously, thos who still speak Swabian, collect the folclore of the zone in recently published volumes (Wohnhas, 2005). Up to today, some of the elderly speak Hungarian not Romanian. After 1989 German schools were reestablished and the younger speak now literary German. The Hungarian-German mix leads to strange associations in the names of the inhabitants, which Hungarian first names and German family names, some not being even translated or written with Hungarian ortography, in most of the cases. In the Hungarian language there are German expressions, not understood in Hungary, such as Kirbáj (a new ortography for Kirchweih) for the day of the Saint of the church instead of búcsú - used in Hungary, or speiz for Speisekammer for deposit, or vájbusli for Weihbusch, a flower composition for $15^{\text {th }}$ of August (Muzeul Judetean Satu-Mare, 2009). Also, an interesting combination of the Swabian kitchen was kept, with some Austrian influences. Some food is 
tipic sătmărene, cum ar fi supa de mazăre. În zilele noastre s-a revigorat festivalul Strudli de la Vállaj printr-un proiect european. În afara caselor, s-au păstrat și anexele gospodărești (Fig. 8).

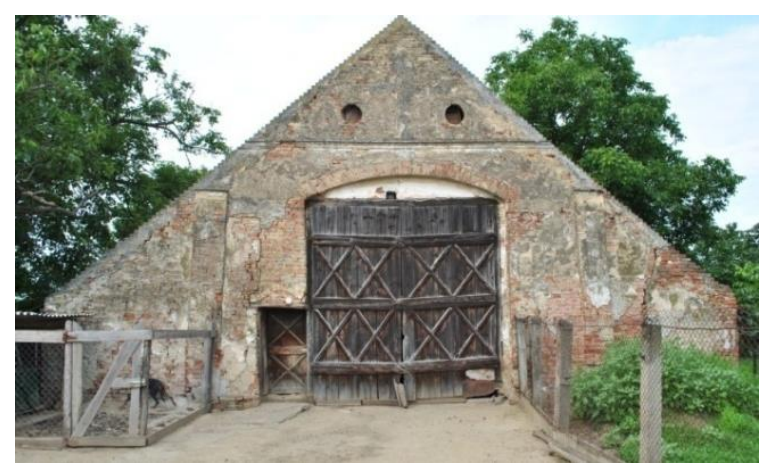

however typical for Sathmar, like the pea soup. Today the strudli festival in Vállaj was revigorated through a European project. Apart of the houses, also the annexes are kept (Fig. 8).

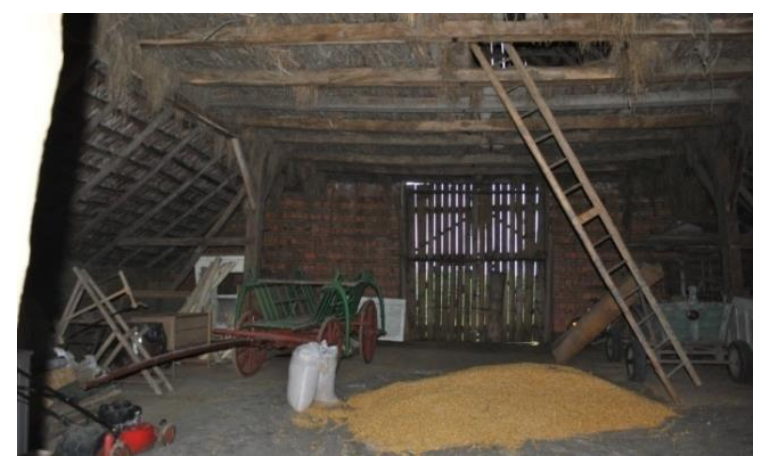

Fig. 8: Anexă gospodărească (șură) din Foieni./ Courtyard annex in Fienen. Foto: M. Bostenaru.

\section{Concluzii}

Cutremurul amintit este motivul pentru care nu se păstrează construcții vernaculare din perioada imigrării, acestea fiind distruse de cutremur cum arată hărțile specialiștilor. Casa strămoșilor subsemnatei datează cu puțin dinainte de 1850, cum am stabilit studiind arborele genealogic și stâlpul martor al casei semnat de aceștia. A fost achiziționată de Forumul Democrat al Germanilor din România din sat și este în curs de renovare pentru a deveni spațiu de expoziție acompaniat de birouri. Din păcate mobila nu s-a păstrat. Dar multe clădiri vernaculare tipice pentru arhitectura șvăbească vernaculară sunt mai noi, printre care și muzeul din Petrești. Această arhitectură se înrudește cu cea din Banat și din zona dunăreană a Ungariei, casă tipică care este reprezentată ca atare și pe etichetele casei Recaș. Casa a constituit și

\section{Conclusions}

The mentioned earthquake is the reason why vernacular constructions from immigration time are not kept, these being destroyed by the earthquake, as the maps of specialists show. The house of the ancestors of the author dates from a little before 1850, date after the family tree and the master beam inscriptions. It was bought by the Democratic Forum of Germans in Romania the village branch and is in course of renovation to become exhibition place and offices for the party. Unfortunately the furniture was not kept. But many vernacular houseing buildings for Swabian architecture are even newer, among them the museum in Petrifeld. This architecture is related to that in Banat and the Danube region of Hungary, the typical house being represented as such also on the Recaș vine bottles. The typical Swabian house was also the model for 
modelul reconstrucției lui Imre Makovecz după catastrofa chimică de la Ajka, păstrând specificul vernacular al zonei. Este caracterizată de o prispă care se încheie cu o ușă în timpanul de la stradă. Sunt mai multe muzee ale satului în Germania care au colectat locuințe vernaculare tipice șvabilor, dintre acestea cele mai vechi fiind în cel din Kürnbach, lângă Bad Schussenried, care în 2018 a împlinit 50 de ani. Am modelat o astfel de casă în 3D după modelul World Housing Encyclopedia pentru locuirea în zone seismice. the reconstruction of Imre Makovecz after the chemical catastrophe in Ajka, keeping the vernacular specifics of the zone. It is characterised by a semiexterior space which closes with a door on the street facade. There are more village museums in Germany which collected vernacular houses of the Swabians, out of these the oldest being found in Kürnbach, close to Bad Schussenried, a museum which was 50 years old in 2018. I modelled such a house in 3D for the World Housing Encyclopedia for housing in earthquake prone zones.

\section{Referinţe/ References}

Bara, I. (2018). Arhitectura „șvăbească“?, comunicare personală.

Bostenaru Dan, M. (2011). Profil: Imre Makovecz, Arhitectura 5, p. 82-85.

Boștenaru Dan, M. (2010). Vernacular and Modernist Housing in Germany and Romania. An Analysis of Vulnerability to Earthquakes. Göttingen: Cuvillier Verlag.

HasImayr, H., Corbea-Hoisie, A. (eds.) (2013) Pluralität als kulturelle Lebensform. Österreich und die Nationalkulturen Südosteuropas. Reihe: Transkulturelle Forschungen an den Österreich-Bibliotheken im Ausland, Band 8, Wien:LIT Verlag.

Kniep, J. (2014). Häuser. Menschen. Geschichten, Bad Schussenried-Kürnbach: Oberschwäbisches Museumsdorf Kürnbach, Schriften Des Oberschwäbischen Museumsdorfs Kürnbach 1.

Muzeul Județean Satu Mare (2009). Urziceni. Ghid cultural şi istoric. Satu-Mare: Muzeul Județean.

Panasiu, G. (2007). Habitatul rural ca expresie a multiculturalitatii in Banatul istoric românesc din timpul administrației austriece 1718-1867, doctorat, , Ion Mincu' University of Architecture and Urban Planning, Bucharest.

Pavlovici (Săbăilă), I.M. (2013). Identitatea modelelor din Luxemburg, doctorat, ,Ion Mincu' University of Architecture and Urban Planning, Bucharest.

Roşu, R. (2015). Zur Identität der Sathmarer Schwaben, Zeitschrift für Balkanologie, 51 (2): 236-253.

http://www.zeitschrift-fuer-balkanologie.de/index.php/zfb/article/view/456/0

Saramago, J. (1982). Memorialul mînăstirii, Bucharest: Polirom.

Schmid, H. (1976). Das oberschwäbische Bauernhaus und seine Darstellung im Freilichtmuseum Kürnbach, Denkmalpflege in Baden-Württemberg, https://journals.ub.uni-

heidelberg.de/index.php/nbdpfbw/article/viewFile/14610/8483 accessed on 23.03.2019. 
Volkmann, S. (2001). Die Architektur des 18. Jahrhunderts im Temescher Banat, http://www.ub.uniheidelberg.de/archiv/1823, doctorat, University of Heidelberg.

Vonház, I. (1931). A szatmármegyei német telepités, Pécs: Dunántúl Pécsi Egyetemi Könyvkiadó és Nyomda.

Wohnhas, J. (2005). Petremr, Kharoulr, Finamr, Khaploanr, Schinalr, Khalmandr, Bescheneedr und andre G'schichta : = Petri, Károlyi, Fényi, Kaplonyi, Csanálosi, Kálmándi, Csárdai és más történetek. Satu-Mare: own publishing.

Zsíros, T. (1983). The Érmellék earthquake of 1834, Acta Geodaet., Geophys., Hung., vol. 18, pp. 129-134. 